\title{
Sea-Level Variability in the Arabian Gulf in Comparison with Global Oceans
}

\author{
Abdullah M. Al-Subhi ${ }^{1,+(D)}$ and Cheriyeri P. Abdulla $1,2,3, *,+$ \\ 1 Department of Marine Physics, King Abdulaziz University, Jeddah 21589, Saudi Arabia; \\ amalsubhi@kau.edu.sa \\ 2 Centre of Excellence in Climate Modeling, Indian Institute of Technology, Delhi 110016, India \\ 3 Department of Physical Oceanography, Cochin University of Science and Technology, Kochi 682016, India \\ * Correspondence: acp1@cusat.ac.in; Tel.: +91-949-555-4475 \\ + These authors contributed equally to this work.
}

Citation: Al-Subhi, A.M.; Abdulla, C.P. Sea-Level Variability in the Arabian Gulf in Comparison with Global Oceans. Remote Sens. 2021, 13, 4524. https://doi.org/10.3390/ rs13224524

Academic Editor: Xiaoli Deng

Received: 12 October 2021

Accepted: 3 November 2021

Published: 10 November 2021

Publisher's Note: MDPI stays neutral with regard to jurisdictional claims in published maps and institutional affiliations.

Copyright: () 2021 by the authors. Licensee MDPI, Basel, Switzerland. This article is an open access article distributed under the terms and conditions of the Creative Commons Attribution (CC BY) license (https:// creativecommons.org/licenses/by/ $4.0 /)$.

\begin{abstract}
The availability of nearly three decades of sea-level estimates from satellite altimetry, for the period from 1993 to the present, is exploited for understanding the climatology of sea level and its long-term variability in the Arabian Gulf (also known as the Persian Gulf) in comparison with global oceans. The Arabian Gulf is characterized by a lower sea level from February to May and a higher sea level from September to December, with a maximum in November and a minimum in April. The variability of sea level in the Arabian Gulf is significantly different and nearly opposite to the pattern of sea-level changes in the adjacent marginal basin, the Red Sea. The analysis of low-passed sea level using the empirical orthogonal function and principal component analysis showed that the first mode of variability explains $87.9 \%$ of the long-term variability and the second mode explains nearly half of the remaining variability (5.6\%). The linear long-term trends in sea level are $2.58 \mathrm{~mm} /$ year for the Northern Arabian Gulf and $3.14 \mathrm{~mm}$ /year for its southern part, with an average of $2.92 \mathrm{~mm} /$ year for the entire Gulf. The analysis of sea level in the Arabian Sea showed a faster rate of sea level rise in the post-2000 period. The long-term linear trend for the post-2000 period in the Northern Arabian Gulf is $4.06 \mathrm{~mm}$ /year, and in the southern Gulf it is $4.44 \mathrm{~mm}$ /year, with an average trend of $4.29 \mathrm{~mm}$ /year. Under the RCP2.6, RCP4.5, and RCP8.5 scenarios, the numerical projections show an expected rise in sea level in the Arabian Gulf by $8.1,1.3$, and $6.8 \mathrm{~cm}$ by 2050, and by 16.9, 17.7, $39.1 \mathrm{~cm}$, respectively by the end of the 21 st century.
\end{abstract}

Keywords: Arabian Gulf; long-term sea level; climate modes; sea-level trend; satellite altimetry

\section{Introduction}

Sea level is one of the primary climate indicators which directly or indirectly impact a major portion of the world population, especially coastal communities in which one-third of the world's population resides [1-3]. Global warming and its impact on the socio-economic system have led to fundamental and strategic research on the ongoing sea-level rise over the past few years [4-6]. In the 21st century, the importance of sea-level research has further increased due to the recent intensification of global warming and its associated impact, resulting in a rise or a fall in regional sea levels. In association with global warming and the melting of ice, sea-level rise is one of the major anticipated consequences of ongoing climate change and the resultant changes in ocean heat content $[2,3]$. Furthermore, for the understanding of physical and biological processes in the upper layer of the ocean, sea level is one of the most important parameters in the recently warming environment [2-8].

The availability of satellite altimetry-derived sea-level estimates provided the opportunity of relatively long-term and, more importantly, continuous observation of sea-level changes for the oceanic region away from the coast all over the globe, which was previously limited to the tidal stations. This helped to a large extent in developing a detailed understanding of ocean dynamics globally, especially in remote areas. The observed sea-level 
variability can either be a deterministic contribution (response of a direct forcing) or a nondeterministic contribution (response of regional small-scale turbulent processes) [3].

The link between sea-level variability and different factors including circulation, atmospheric pressure changes, wind stress, and large-scale oscillations is very complex [9-14]. Numerical models are used for the detailed understanding of the contribution of different factors to the overall variability. Recent Intergovernmental Panel for Climate Change (IPCC) reports showed that the projected sea level for the 21st century shows significant variability at the regional scale [1,2]. Considerable efforts have been taken to understand long-term variability in recent decades at the global as well as the regional scale $[2-12,15,16]$. Tide gauge measurements and altimetry have shown that sea level rose rising during the last century and is continuing at a faster rate in the present century. The projected sea level for different scenarios from the IPCC also agree with a future increase in the rate of sea-level rise.

The region of the Arabian Gulf (Figure 1) along with the Strait of Hormuz and the Gulf of Oman is one of the busiest shipping routes in the world, as the region is also important for the oil industry. The Arabian Gulf is geographically located between $23^{\circ} \mathrm{N}$ and $31^{\circ} \mathrm{N}$, and between $47^{\circ} \mathrm{E}$ and $56^{\circ} \mathrm{E}$. The number of ships passing through this region is very high, with, on average, a minimum of one ship passed through the Strait of Hormuz every 6 minutes [17]. The width of the Arabian Gulf varies from as narrow as $56 \mathrm{~km}$ at the strait to $338 \mathrm{~km}$ inside the Gulf. The region is approximately $2.39 \times 10^{5} \mathrm{~km}^{2}$ in area, with a length of approximately $1000 \mathrm{~km}$ from the strait to the northern end. The average depth of the region is $36 \mathrm{~m}$ and the average volume is $8.63 \times 10^{3} \mathrm{~km}^{3}$. The Arabian Gulf is connected to the Indian Ocean through the narrow Strait of Hormuz. Sills are absent at the entrance of the Strait of Hormuz, and the depth at the strait rapidly increases from 100 to $2000 \mathrm{~m}$ within just $200 \mathrm{~km}$ towards the Indian Ocean side.

The meteorological and oceanographic conditions of the Arabian Gulf have many similarities with that of the adjacent Mediterranean Sea and Red Sea, except in the depth of the basin. The depth is less than $100 \mathrm{~m}$ for Arabian Gulf, while it reaches more than $2000 \mathrm{~m}$ in both the Mediterranean Sea and the Red Sea. The depth of the northwestern and western Arabian Gulf is shallower than the rest of the region. A trough extends from the Strait of Hormuz to the Northern Arabian Gulf, which collects denser bottom water and guides outflow to the Arabian Sea.

The Arabian Gulf is characterized by intense evaporation due to the surrounding arid climate and its shallow nature. The evaporation is much higher than the freshwater input from both river discharge and precipitation. The average annual evaporation of the Arabian Gulf is approximately $2 \mathrm{~m}$ [17-20]. Annually, the region experiences a net gain of surface heat flux of $3 \mathrm{~W} / \mathrm{m}^{2}$. Interestingly, the amount of evaporation is higher during winter than summer even in the presence of higher temperatures during summer [20]. The contribution of precipitation to the annual freshwater budget is less than that of river discharge [6]. The river discharge mostly occurs in the northern end of the Arabian Gulf through "Shatt al-Arab", which combines three rivers, namely the Tigris, Euphrates, and Karun. The discharge from Karun is higher than the other two rivers [17,19].

The region of the Arabian Gulf is characterized by an arid climate with dry air and clear skies as this region marks the boundary between the Hadley-cell and the mid-latitude weather systems. The prominent wind system in the region is from the northwest direction (Shamal winds) throughout the year. The wind is relatively stronger during winter, with greater abruptness and force than in summer. Apart from the Shamal wind, a summer wind called Kaus in Arabic (or Shakki in Persian) blows from the southeast direction ahead of the approaching cold front. The wind Kaus may reach gale force before the passage of the front and the onset of small winds. The Shamal winds spread from the northwest to the south, while Kaus winds are mostly experienced on the eastern seaboard. Furthermore, the sea breeze is common along the coast of the Arabian Gulf due to the temperature difference between land and sea. This has a vital impact on driving the surface pollutants towards the coast faster than usual $[6,17,19]$. 


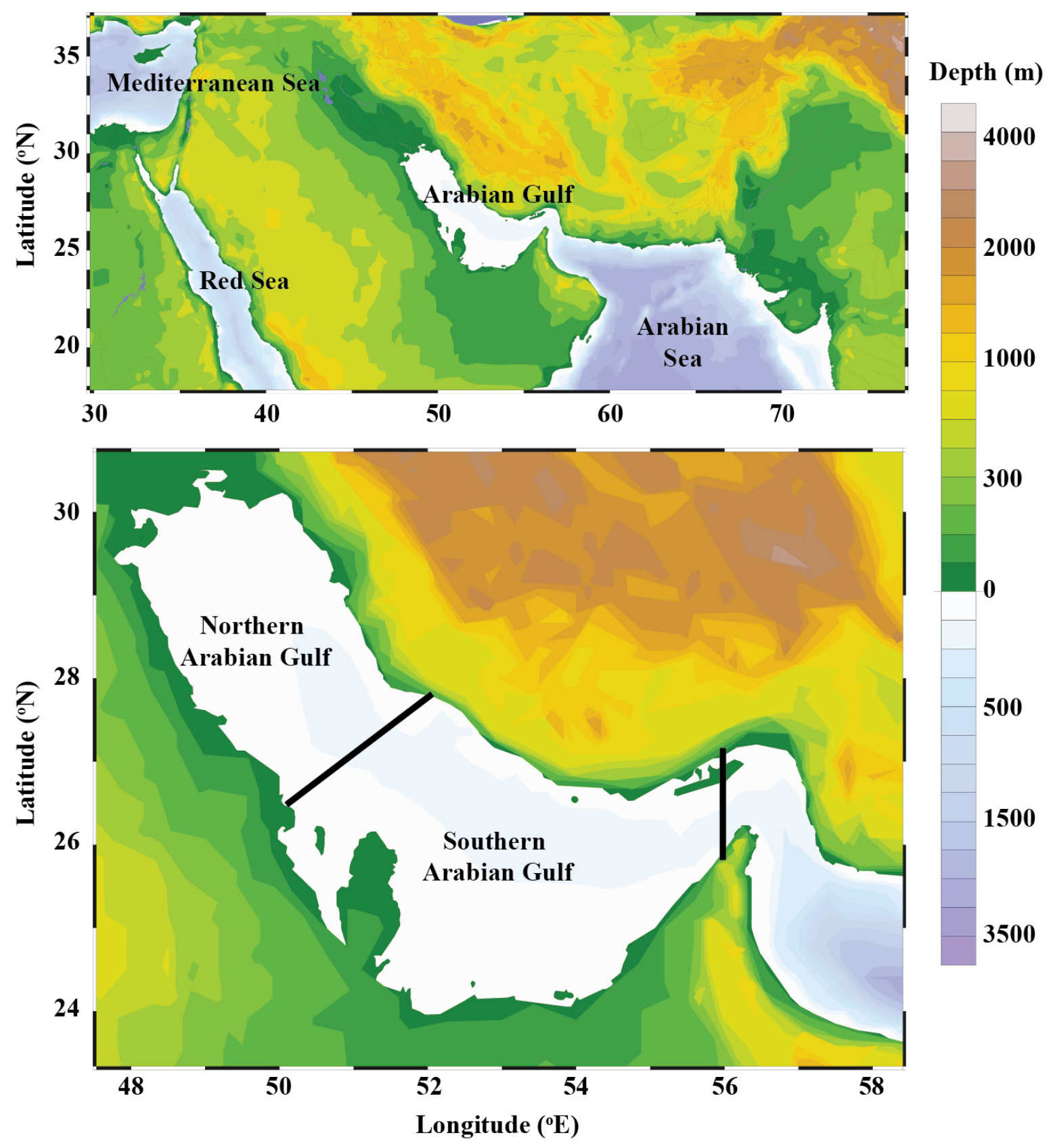

Figure 1. Study area. Northern, and southern regions of the Arabian Gulf are marked.

The circulation in the Arabian Gulf is mainly associated with tides, winds, and densitydriven currents. The contribution of the tide is significant at smaller scales such as a horizontal length of less than $10 \mathrm{~km}$ and a period of one day. The residual circulation is mainly driven by the wind system and the density gradient [21]. Wind-dominated circulation is prominent in the northern side, while density-dominated circulation prevails in the central and southern regions. The exchange of high salinity and low salinity water occurs at the Strait of Hormuz. The denser surface water formed by intense evaporation sinks and outflow to the Gulf of Oman as a high-salinity undercurrent. The Arabian Gulf is characterized by reverse estuary flow similar to that of the Mediterranean Sea. Additionally, a prominent secondary coastal current is visible in the opposite direction (southward) in the direct measurements as well as satellite images along the Iranian coast $[17,21]$.

Sea-level variability in the Arabian Gulf is mainly driven by the meteorological conditions in the region and the water exchange along the Strait of Hormuz [6,22]. Analysis based on meteorological parameters has shown the dominance of annual along with semi- 
annual variations in the sea level [6]. Higher sea levels are observed during summer and lower sea levels are observed during winter [23]. Sultan [6] reported that the contribution of pressure to the sea-level variability is approximately $75 \%$, while that of the steric effect is $25 \%$.

Previous studies based on tide gauges in the Arabian Gulf reported different values for the long-term trend in sea level mainly due to the difference in the selected period for the study $[6,24,25]$. The analysis based on an 11-year record from two tide gauges showed an average sea-level trend of $2.1 \mathrm{~mm} /$ year [6]. An elaborated study based on nine tide gauges and a longer time scale showed a trend of $1.7 \mathrm{~mm} /$ year [24]. A further study based on altimetry data for 1990 to 1999 reported a faster rate of sea-level rise (2.8 mm/year) at the Northern Arabian Gulf [25]. A subsequent study focusing on the entire Gulf by Hosseinibalam [26] showed that the rate of the rise in sea level is $2.34 \mathrm{~mm} /$ year. Alothman [27] reported that the mean rate of sea-level rise is $2.4 \mathrm{~mm} /$ year based on 1979 to 2007 data. Globally, the recent records from the satellite altimetry display a faster sea-level rise of $3.3 \pm 0.5 \mathrm{~mm} /$ year for the 1993-2017 period $[2,4,28]$. The short-term sea level has complex variability, with the major tide varying regionally from diurnal to semidiurnal and mixed types.

In the Arabian Gulf, most of the studies are based on tide gauges for a few locations and different periods, resulting in considerably different values for the rate of sea-level rise. Additionally, the information on interannual variability and the link to climatic modes and remote forces are not clearly understood. To fill this gap, the present study investigated the mean and interannual variability of sea level in the Arabian Gulf, compared the longterm variability with that of the other global ocean basins, and discussed the associated dynamics. This paper is organized as follows: the information on the datasets used and methodology adopted is given in Section 2; results are presented in Section 3 and the discussion is presented in Section 4 , followed by concluding remarks in the final section.

\section{Materials and Methods}

\subsection{Data}

The datasets used in the study included remote sensing data of sea-level anomalies, remote sensing data of sea-surface temperature, re-analysis wind data, and secondary data of climate indices.

Satellite observations of sea-level data were obtained from AVISO (http:/ / www. aviso.altimetry.fr/ (access on 7 July 2021)) for the period from 1993 to the present on a spatial resolution of $0.25^{\circ} \times 0.25^{\circ}$. The data were prepared by optimal interpolation and merging of data from Jason-3, Jason-2, Jason-1, ENVISAT, T/P, HY-2A, Sentinel3A, Saral/AltiKa, ERS1/2, Cryosat-2, GFO, and processing with the help of DUACS multi-mission altimeter data processing system. The mean sea level for the 1993 to 2012 period was used for the computation of sea-level anomaly maps. The absolute dynamic topography and geostrophic currents are also available along with sea-level anomaly maps. The interpolation system (DUACS multi-mission altimeter data processing system) uses the along-track measurements to produce reprocessed (delayed-time or DT) maps of absolute dynamic topography and sea-level anomalies (for more details, refer to [29,30]).

Satellite data of sea surface temperature (SST) were obtained from Advanced Very High-Resolution Radiometer (AVHRR) Pathfinder Version 5 with the resolution of $4 \mathrm{~km}$, which is the longest SST time series of physical measurement from space available at the global ocean (https://podaac.jpl.nasa.gov/dataset/ (access on 7 July 2021)). The development of AVHRR SST was accomplished by the National Oceanographic Data Centre (NODC) by the National Oceanic and Atmospheric Administration (NOAA). AVHRR is a space-borne scanning sensor and it falls under the family of polar-orbiting and ornamental satellites by NOAA, having an operational legacy that traces back to infrared observation satellites (TIROS-N) launched to orbit in 1978. The AVHRR swath is around $2400 \mathrm{~km}$ and the satellite is Sun-synchronous. The collection of novel satellite platforms used comprises NOAA-7, 9, 11, 14, 16, 17, and 18. The SST data by AVHRR include both day and night at 
daily, 5-day, monthly, and yearly temporal scales. The nighttime monthly mean data were used in the present analysis (for more details, refer [31]).

The wind data were received from Climate Forecast System Reanalysis (CFSR) by National Centers for Environmental Prediction (NCEP), which is a third-generation reanalysis product freely available on a global scale. CFSR is produced by coupling of atmosphere, ocean, land surface and sea ice for the best estimate of the sea state. The data can be accessed from the website https:/ /rda.ucar.edu/datasets/ds094.1/ (access on 7 July 2021). The data are available at an hourly time scale and $0.2^{\circ} \times 0.2^{\circ}$ spatial resolution. The CFSR product is from a combination of coupling of atmosphere and ocean along with interactive sea-ice model, and assimilation of satellite radiances (for more details, refer [32]).

\subsection{Methods}

FERRET is one of the most widely used open-source scientific data analysis tools, and is an interactive computer environment for visualization and analysis specially designed for meteorological and oceanographic data analysis. Similarly, the climate data operator (CDO) is a collection of command-line operators helpful to analyze and manipulate the climate datasets of different formats including the Network Common Data Form (NetCDF). Both FERRET and CDO were used for the analyses. FERRET was used for time series analyses, while CDO was used for the estimation of annual, seasonal, and monthly climatology.

Wavelet, empirical orthogonal function (EOF), and principal components (PC) analyses were used to explore underlying signals in the time series. Regression analysis was used to explore the relation between sea level in the Arabian Gulf and different climate phenomena such as the Indian Ocean Dipole or IOD (Dipole Mode Index from https: / / www.esrl.noaa.gov/psd/gcos_wgsp/Timeseries/DMI/ (access on 7 July 2021)), El-Nino Southern Oscillation or ENSO (Multivariate ENSO Index from https:/ / www.esrl.noaa. gov/psd/data/correlation/meiv2.data), and North Atlantic Oscillation or NAO (North Atlantic Oscillation Index from https:/ / www.esrl.noaa.gov/psd/data/correlation/nao.data (access on 7 July 2021)).

The seasons in the Arabian Gulf were classified into winter (December to February), spring (March to May), summer (June to August), and fall (September to November). The study region (Arabian Gulf) was divided into the Northern Arabian Gulf and Southern Arabian Gulf as shown in Figure 1.

\section{Results}

\subsection{Climatological Features in Mean Sea Level: Annual, Seasonal, and Monthly}

\subsubsection{Annual}

The annual climatology of sea level, prepared from monthly mean sea-level data covering nearly three decades from 1993 to 2020, is shown in Figure 2. The sea level in the Arabian Gulf is generally higher on the southern and western sides. The presence of mesoscale eddies is visible from the existence of multiple patches in the annual climatology. The figure shows the presence of a cyclonic eddy along the eastern coast near the Strait of Hormuz, showing the possible propagation of cyclonic and anti-cyclonic eddies from the Arabian Sea to the Gulf along the coast as coastal high and low centers of sea level.

The annual mean sea level in the Arabian Gulf is relatively lower than that of adjacent marginal seas (Mediterranean Sea and Red Sea) and gulfs (Gulf of Oman and Gulf of Aden). The climatologically averaged annual mean sea level for the Arabian Gulf is $3.40 \mathrm{~cm}$ (Figure 2), while those for the Mediterranean Sea and the Red Sea are, respectively, 3.68 and $4.02 \mathrm{~cm}$, and those for the Gulf of Oman and Gulf of Aden are, respectively, 3.49 and $4.08 \mathrm{~cm}$ (Figure 3). 


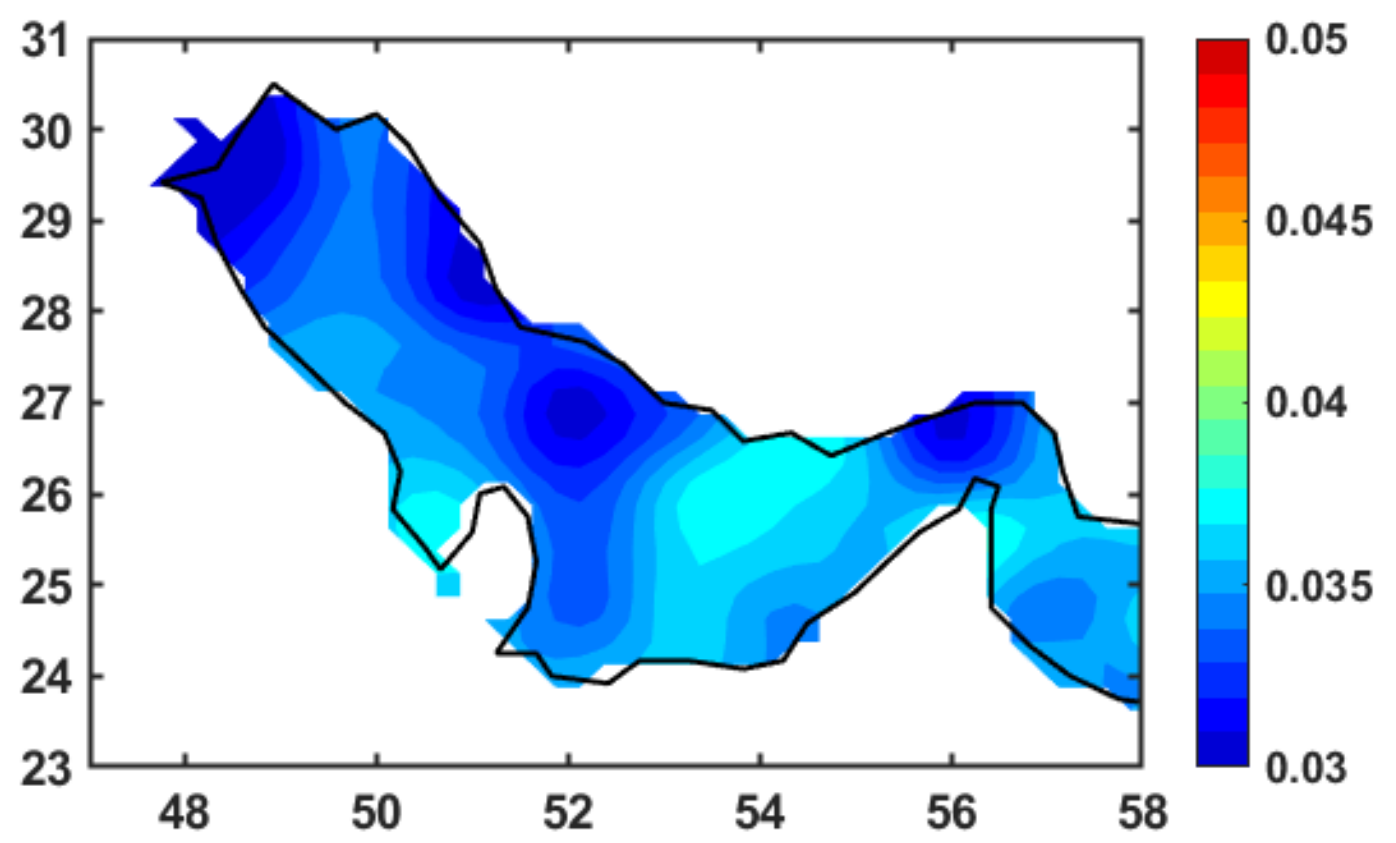

Figure 2. Annual climatological mean sea level for the Arabian Gulf. Sea level given in meters.

\subsubsection{Seasonal}

Sea level in the Arabian Gulf is higher during fall compared to the rest of the year (Figure 4). A significant spatial and temporal variability is observed in the Arabian Gulf sea level from season to season. During winter, the northern Gulf has a relatively lower sea level, while the rest of the region has a higher sea level. This pattern continues in spring also, with the northern lower sea level extended to a wider area towards the southwestern coast. The pattern is reversed during summer with higher sea level towards the northern and western sides. An extension of lower sea level from the Gulf of Oman to the Arabian Gulf through the Strait of Hormuz is also visible. During fall, the northern higher sea level almost spread into the entire Gulf. The maximum and minimum sea levels are observed during the fall and spring seasons, respectively. The results show that the fluctuations in sea level outside the Arabian Gulf gradually propagate into the Gulf through the Strait of Hormuz as a "tongue" of a high or low level and moves towards the Northern Arabian Gulf.

\subsubsection{Monthly}

Maps of the monthly mean sea level are shown in Figure 5. The northern low in sea level began by December in the northern end and spreads to the south gradually during January to April, and weakens thereafter. The pattern reverses by July, where the northern Gulf experiences a higher sea level and intensifies to a wider area in the following months. The maximum sea level in a seasonal cycle is observed during November and the minimum during April. Figure 5a shows that the extension of a higher sea level from the Gulf of Oman (or the Arabian Sea) to the Arabian Gulf is limited to the southeastern side during January. The condition is similar in almost all months (Figure 5b-1), where the signatures of sea level variability are propagated to the Arabian Gulf through the Strait of Hormuz but largely limited to the southern and eastern Gulf. A significant difference is observed in sea-level variability between the Arabian Gulf and the Gulf of Oman due to the presence of the Strait of Hormuz as a barrier. 


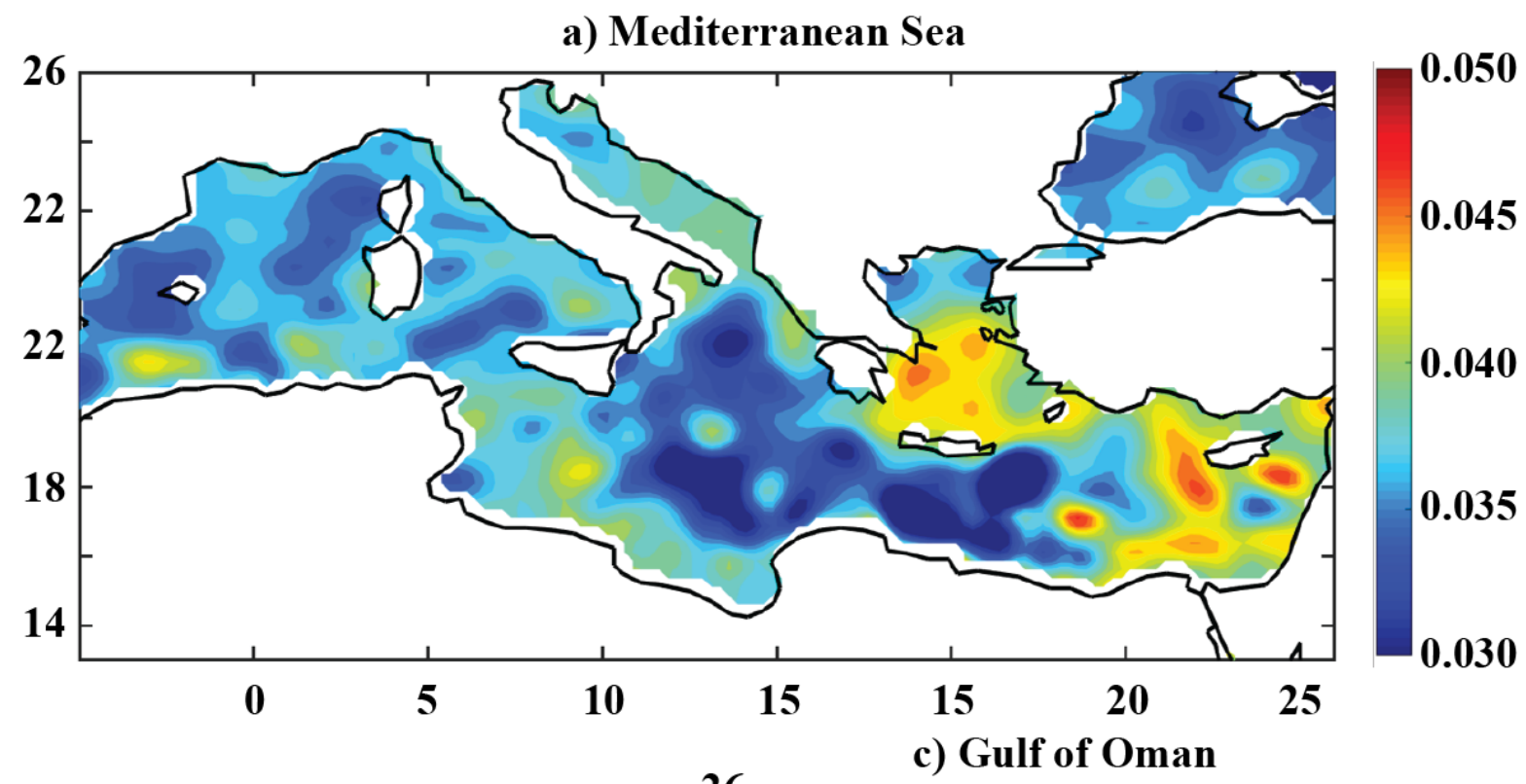

b) Red Sea

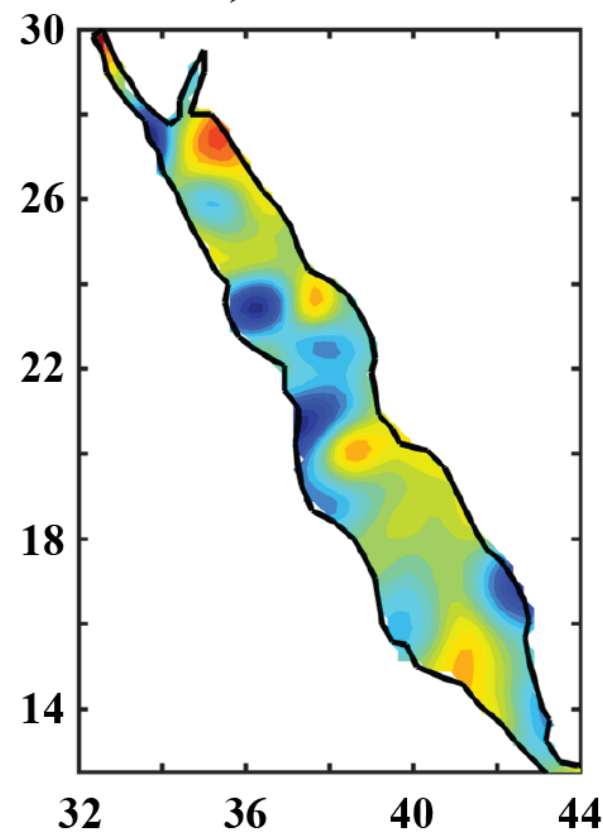

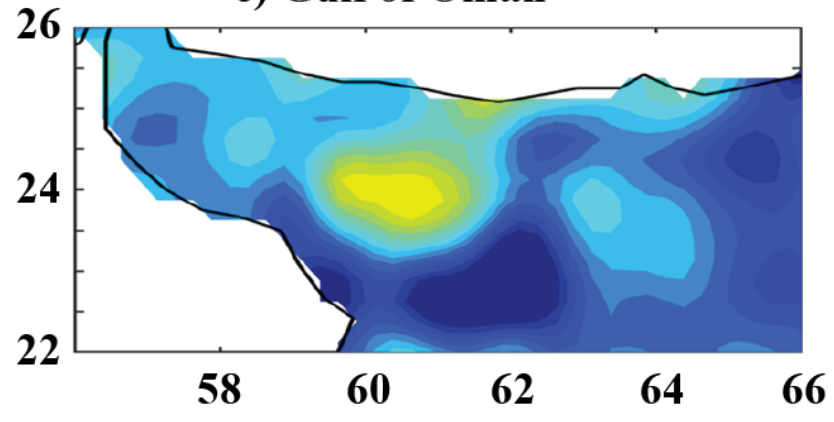

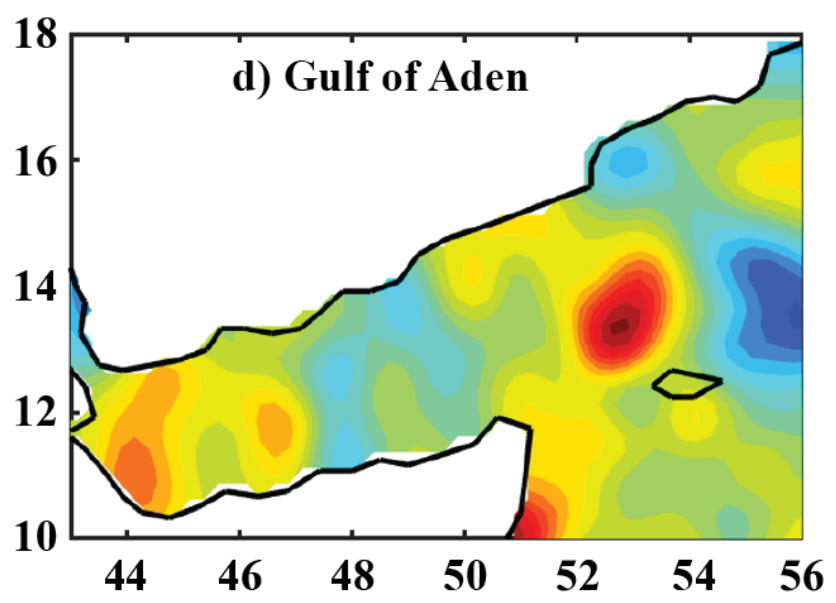

Figure 3. Annual climatological mean sea level for the adjacent marginal seas and gulfs. Sea level given in meters.

3.2. Comparison of Seasonal Cycle in the Arabian Gulf with That of the Mediterranean Sea, the Red Sea, and the Arabian Sea

The seasonal cycle in the Arabian Gulf is compared with the adjacent basins, namely the Mediterranean Sea, the Red Sea, and the Arabian Sea (Figure 6). The seasonal cycle in the Mediterranean Sea is characterized by a lower sea level during spring and a higher sea level during late summer, with a minimum in March and a maximum in October. The Red Sea's seasonal variability is characterized by a higher sea level between December and January and a lower sea level during summer, almost opposite to the Mediterranean Sea pattern. The seasonal variability of sea level in the Arabian Sea is characterized by higher sea level during the months of April-May and lower sea level during the months of November-December. 
a) winter
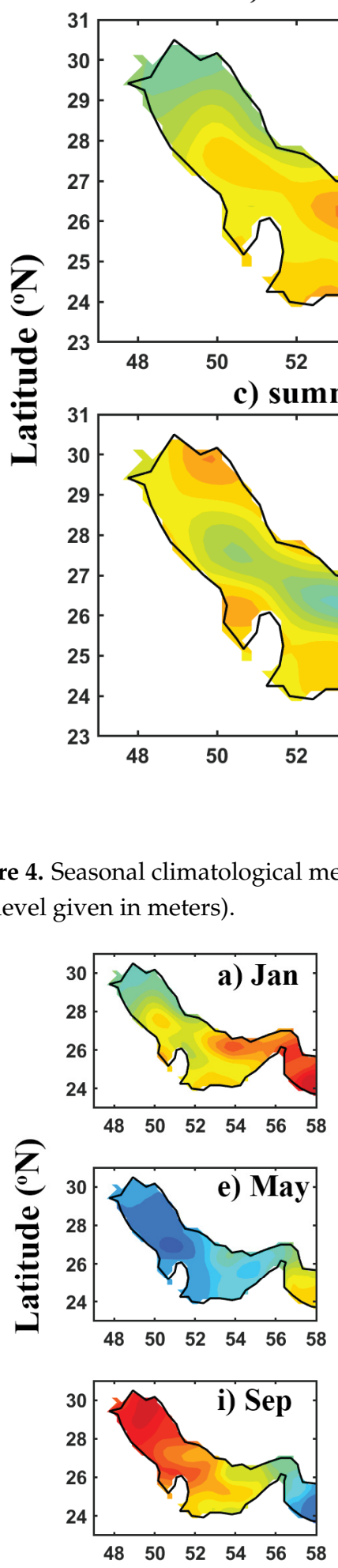
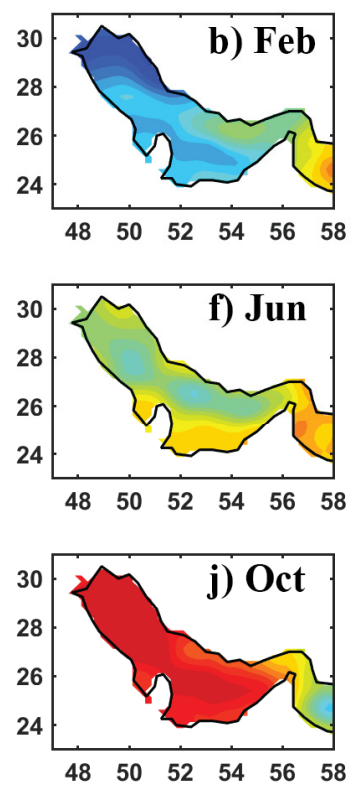

b) spring

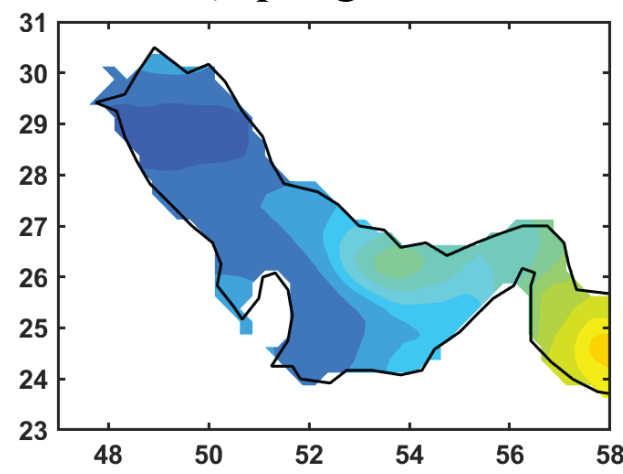

d) fall

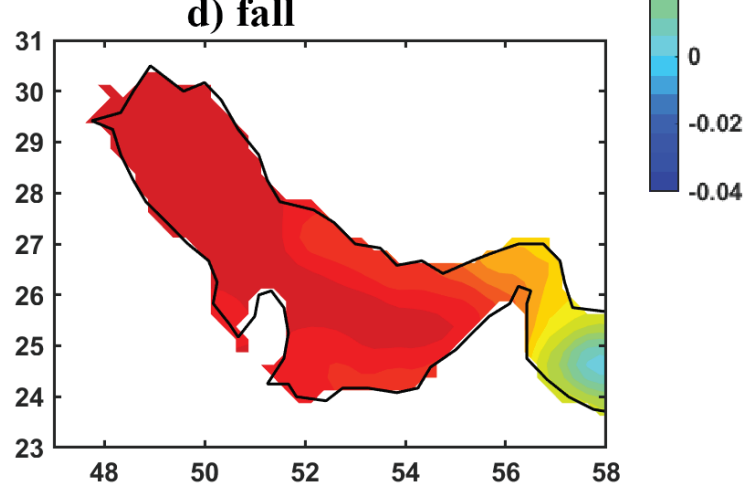

$\left({ }^{\circ} \mathbf{E}\right)$

Figure 4. Seasonal climatological mean sea level during (a) winter, (b) spring, (c) summer, and (d) fall for the Arabian Gulf (sea level given in meters).

\section{Longitude $\left({ }^{\circ} \mathbf{E}\right)$}

Figure 5. Monthly climatological mean sea level for the Arabian Gulf (sea level given in meters). 

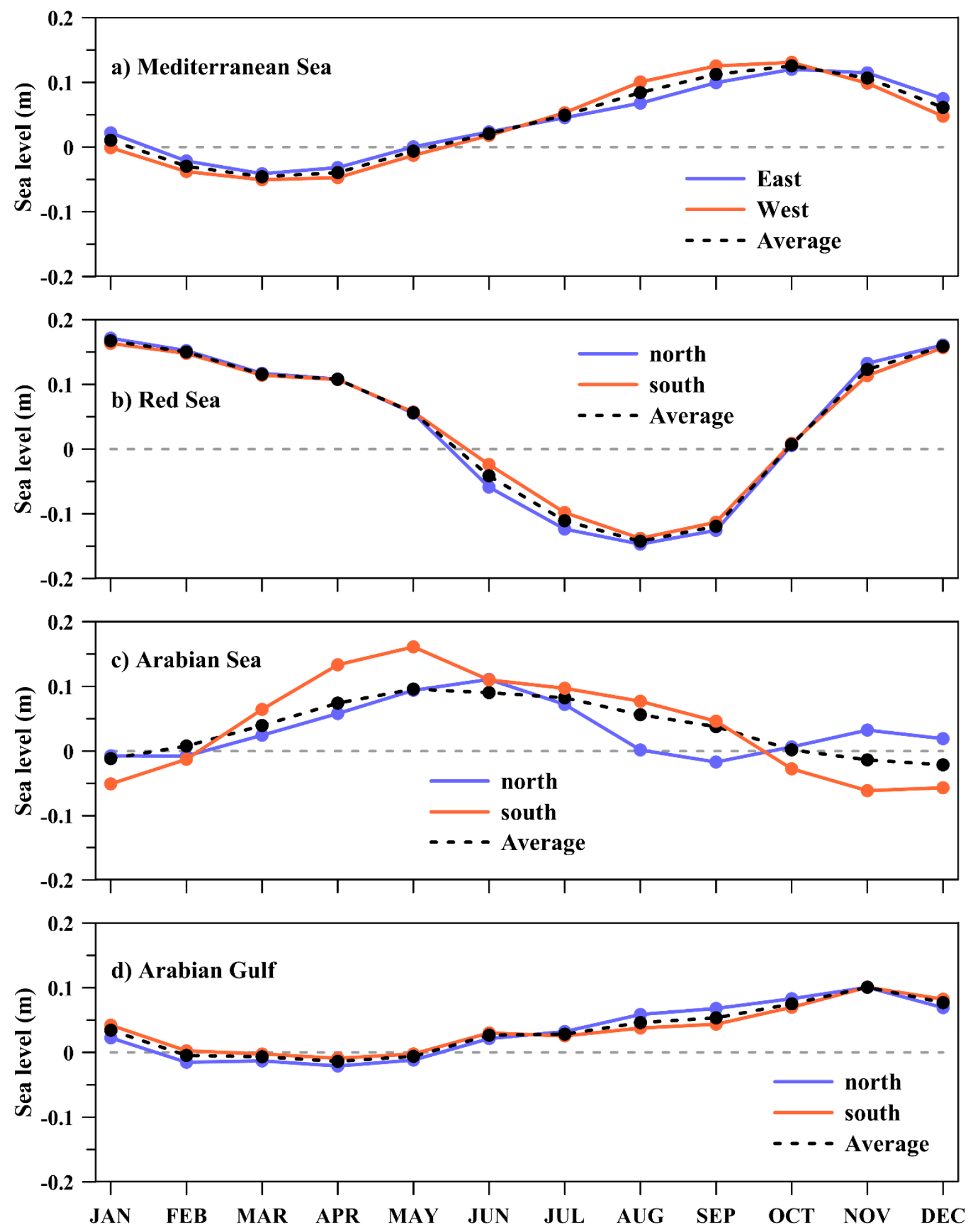

Figure 6. Seasonal cycle of monthly mean sea level for the Mediterranean Sea, the Arabian Sea, and the Arabian Gulf (sea level given in meters).

The observed variability of sea level in the Arabian Gulf has a significant difference from the directly connected Arabian Sea. Arabian Gulf is characterized by a lower sea level from February to May and a higher sea level from September to December, with a maximum in November and a minimum in April. The seasonal variability of sea level in the Arabian Gulf is almost opposite to the pattern of sea level changes in the Red Sea, 
while the mean seasonal cycle in the Arabian Gulf is almost matching with that of the Mediterranean Sea.

The Northern and Southern Arabian Gulf have a similar variability in sea level. The Northern Arabian Gulf's sea level is comparatively lower during winter and higher during summer. However, the range of differences between the northern and southern sides is relatively small. The regional variability within the basin is similar for the Mediterranean Sea and the Red Sea, while the Arabian Sea has a slightly higher difference between the northern and southern sides.

\subsection{Interannual and Long-Term Variability of Sea Level \\ 3.3.1. Interannual and Long-Term Variability}

The variability of sea level at the interannual scale is analyzed separately for northern and southern sides and shown in Figure 7. The northern and southern sides follow a similar pattern of sea-level variability at the interannual time scale. The years 1995, 2000, 2005, 2009,2011 , and 2016 were observed to have visible fall events, while 2007, 2010, 2015, and 2019 , etc., experienced rise events in sea level. The sea level was observed to demonstrate a long-term increase from 1993 to the present. The interannual variability for winter, spring, summer, and fall seasons is separately analyzed and shown in Figure 8. The northern and southern parts of the Gulf have a similar pattern of variability for most of the years, with some non-linearity in a few years.
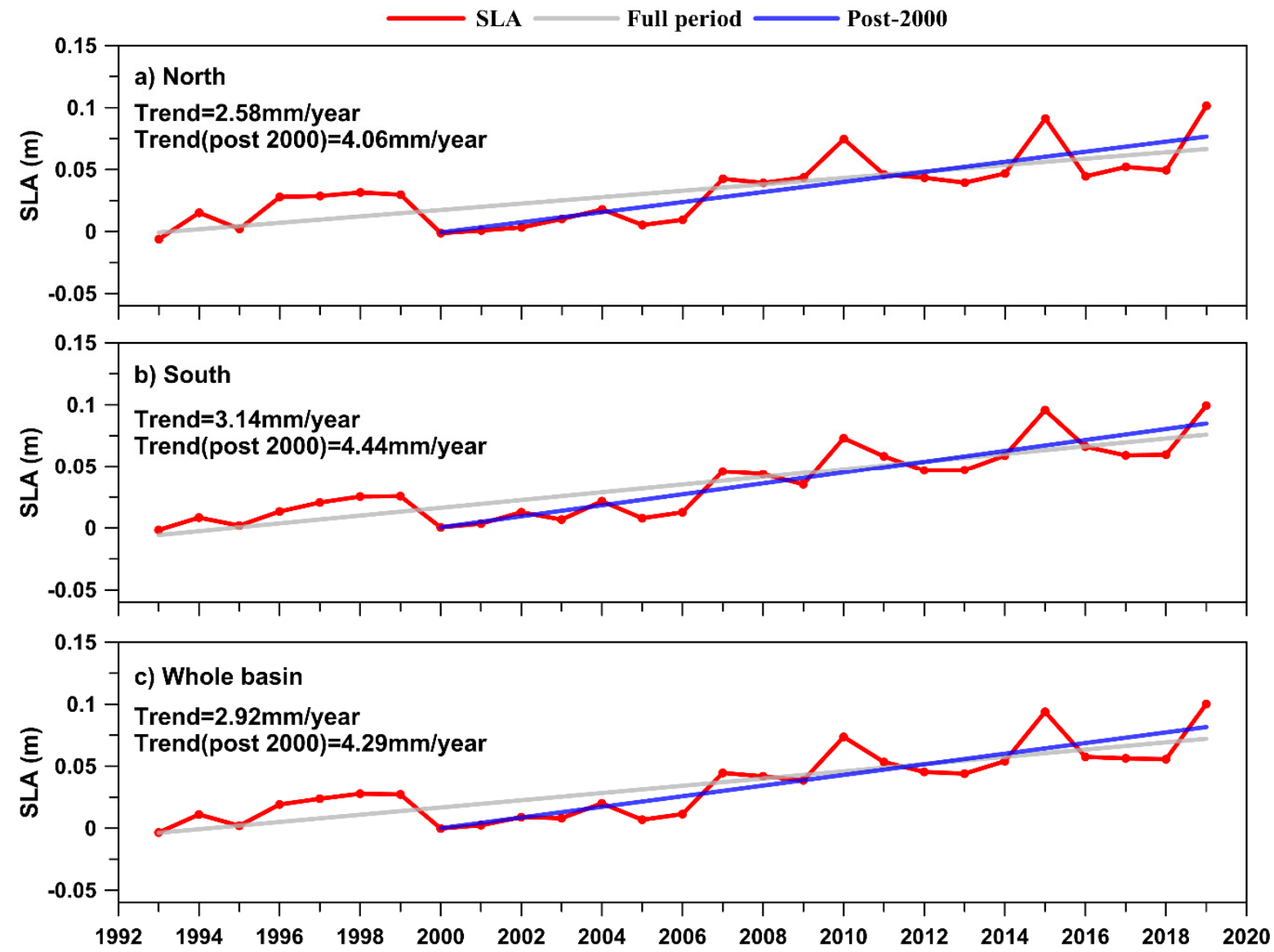

Figure 7. Annual mean sea level in the Arabian Gulf for the northern (red), southern (blue), and whole (black) basin. The solid grey and red line represent linear trends for the full period and the post-2000 period, respectively. 

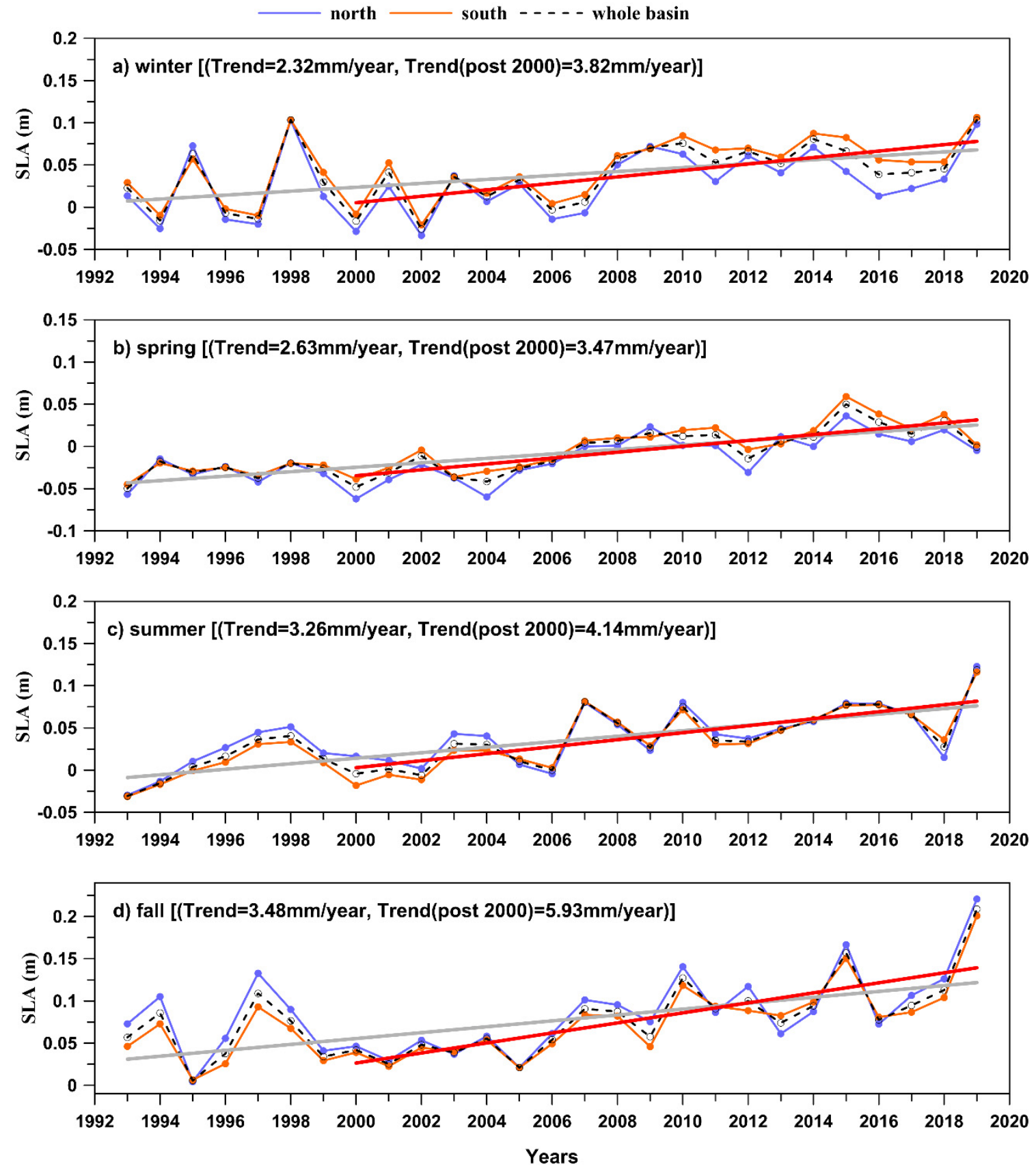

Figure 8. Seasonal mean sea level in the Arabian Gulf for the (a) winter, (b) spring, (c) summer, and (d) fall. Blue, orange, and dashed black lines represent the northern, southern, and whole basins, respectively. The solid grey and red line represent linear trends for the full period and post-2000 period, respectively.

The interannual variability is minimum during spring, while the intensity is high during the winter and fall seasons. A relatively intense rise in sea level is observed during the winters of the years 1995 and 1998. The fall seasons of 1994 and 1997 also experienced a similar variability, where the 1-year difference between the events (i.e., 1994 fall and 1995 winter) is due to the fall season of the year being compared with the winter of the next year. The analysis based on empirical orthogonal function (after removing the seasonal) shows that the first mode of variability explains almost $88 \%$ of the observed variability, and the second mode of variability explains almost half of the remaining variability (Figure 9). 


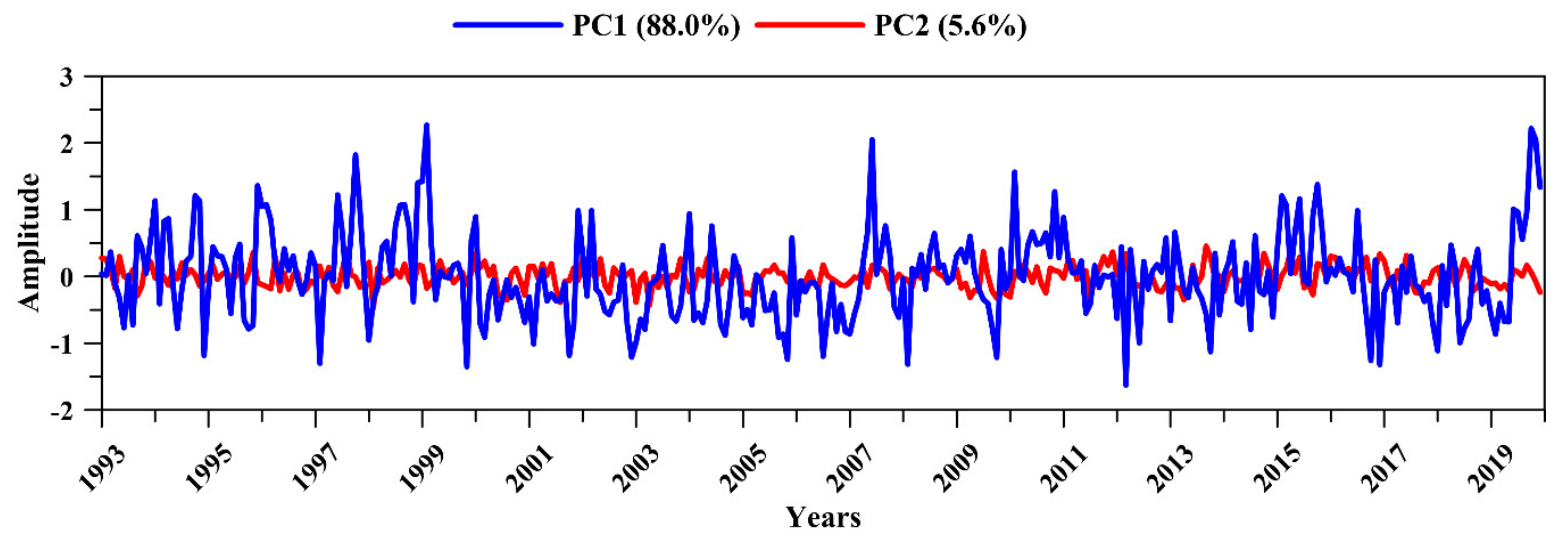

Figure 9. The dominant modes of variability from the principal component analysis for sea level after removing seasonal cycle.

\subsubsection{Long-Term Trend in Annual and Seasonal Mean Sea Level}

The linear long-term trends in sea level are $2.58 \mathrm{~mm} /$ year for the Northern Arabian Gulf and $3.14 \mathrm{~mm} /$ year for the Southern Arabian Gulf. The overall trend is $2.92 \mathrm{~mm} /$ year. The analysis of sea level in the Arabian Sea shows a faster rate of sea-level rise in the post-2000 period. To assess whether the same trend exists in the Arabian Gulf, the sea level in the 21st century, from 2000 to the present, is separately examined.

The long-term linear trend for the post-2000 period in the Northern Arabian Gulf is $4.06 \mathrm{~mm}$ /year, and for the Southern Arabian Gulf it is $4.44 \mathrm{~mm}$ /year, with an average trend of $4.29 \mathrm{~mm}$ /year. The seasonally averaged sea-level time series shows a relatively higher rate of increase in sea level during the summer and fall seasons (higher than $3 \mathrm{~mm} / \mathrm{year}$ ), while the winter and spring seasons have lower rates (less than $3 \mathrm{~mm}$ /year).

Similar to the annual mean sea level time series, the seasonal variability of sea level also has consistent variability between both the northern and southern Gulf. The linear trend for the entire period during the winter, spring, summer, and fall seasons is, respectively, $2.32,2.63,3.26$, and $3.48 \mathrm{~mm} /$ year, while that during the post-2000 period is, respectively, $3.82,3.47,4.14$, and $5.93 \mathrm{~mm} /$ year. The fall season is characterized by the highest rate of increase in sea level. The seasonal mean sea level is also highest during the fall season.

The level of the Arabian Sea experienced an abrupt rise in the rate of sea-level rise during the post-2000 period. The results show that the sea level in the Arabian Gulf also experienced a similar increase in the rate of sea-level rise.

\subsubsection{Projected Sea-Level Changes in the Arabian Gulf}

The expected sea-level projection under the RCP2.6, RCP4.5, and RCP8.5 scenarios for the Arabian Gulf is shown in Figure 10. The predicted sea level for the Arabian Gulf for the year 2050 is $52.9,50.7$, and $54.9 \mathrm{~cm}$, and for the year 2100 it is $61.7,67.1$, and $87.2 \mathrm{~cm}$, respectively. According to this, the sea level is expected to rise by $8.1,1.3$, and $6.8 \mathrm{~cm}$ by 2050 for the scenarios RCP2.6, RCP4.5, and RCP8.5, and by 16.9, 17.7, and $39.1 \mathrm{~cm}$, respectively, by the end of the 21st century.

\subsection{Comparison of Interannual and Long-Term Variability in Sea Level with Adjacent Marginal} Seas and Major Ocean Basins

The sea-level variability in the adjacent marginal seas and major world ocean basins are analyzed and compared with the sea-level variability in the Arabian Gulf (Figures 11 and 12). The time series of annual mean sea level is overlaid in the figures for easy comparison. The eastern and western sides' sea-level trends are separately estimated when the longitudinal extension of the basin is relatively large. The results show that the sea level is increasing in all basins with slight differences in the rate of increase. 


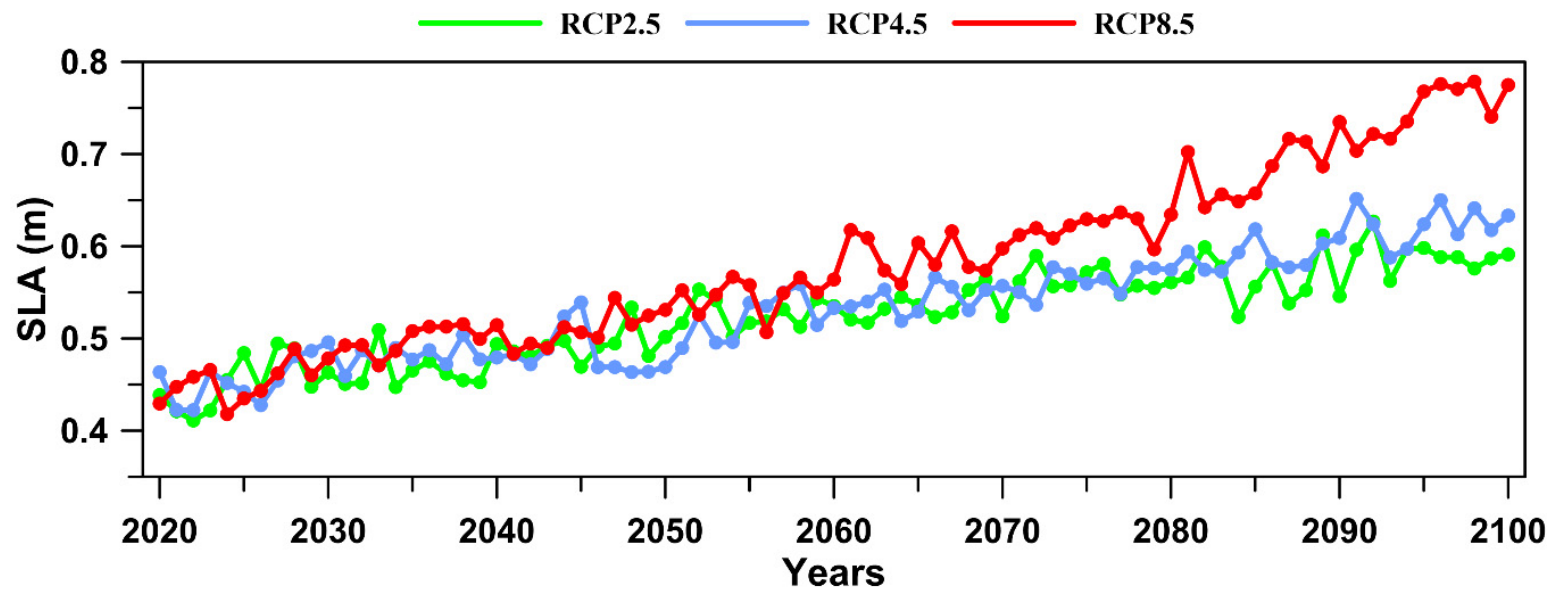

Figure 10. Projected SLA for the Arabian Gulf.
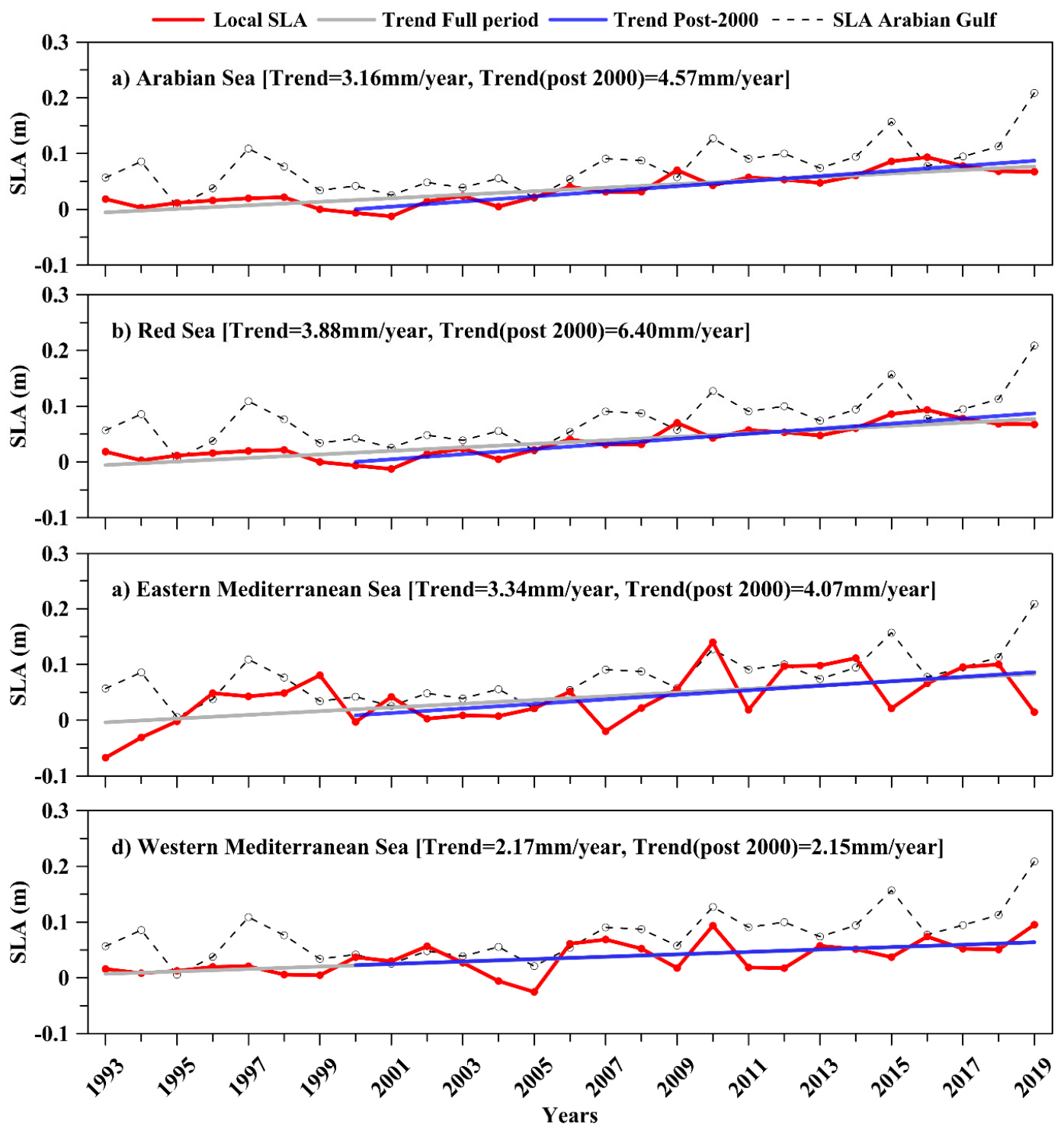

Figure 11. Annual mean sea level for (a) the Arabian sea, (b) the Red Sea, (c) the Eastern Mediterranean Sea, and (d) the Western Mediterranean Sea. The trends are shown in solid lines for the post-2000 period (blue), and the full period (grey). 


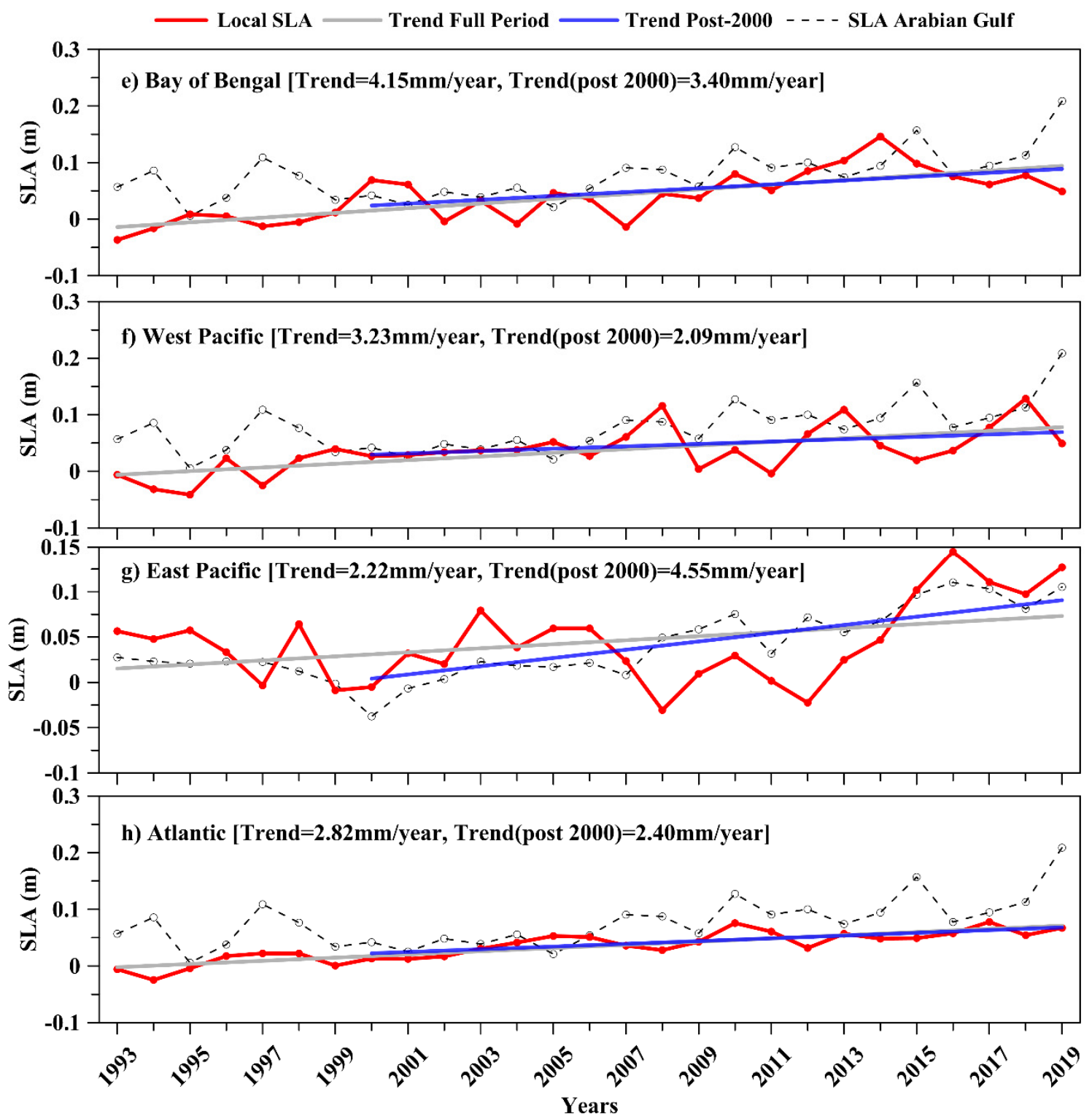

Figure 12. Same as in Figure 11, but for (e) the Bay of Bengal, (f) the West Pacific, (g) the East Pacific, and (h) the Atlantic.

The Arabian Sea is experiencing sea-level rise of $3.16 \mathrm{~mm} /$ year, and the Red Sea is experiencing a rise of $3.88 \mathrm{~mm}$ /year. The Mediterranean Sea is experiencing a trend of $3.34 \mathrm{~mm}$ /year on the eastern side and $2.17 \mathrm{~mm} /$ year on the western side. For the post-2000 period, the sea level is increasing at a faster rate for most of the region, with $4.57 \mathrm{~mm} /$ year for the Arabian sea, $6.40 \mathrm{~mm}$ /year for the Red Sea, and $4.07 \mathrm{~mm}$ /year on the Eastern Mediterranean Sea.

As already reported by previous research, the long-term linear trend in sea level differs regionally $[2,3,7,8,33]$. The observed trend in sea level is consistent with global warming and an associated increase in sea level. It is also important to note that the pattern of interannual sea-level variability in the Arabian Gulf is different from the pattern of sea-level change in the selected basins. However, the observed trend level matches that of the Arabian sea, which is directly connected through the Strait of Hormuz and the Gulf of Oman. This could be due to the dominance of local forces over remote forces.

\subsection{Impact of Global Warming: Results from Sea Surface Temperature}

To understand how ongoing global warming impacts the sea-level variability of the Arabian Gulf, the change in sea surface temperature is examined. The wavelet analyses 
for monthly mean values of sea level and SST are matching well where the variability is dominated by the seasonal signal (Figure not shown). The results for low-passed values (seasonal and higher frequency, $<12$ months, signals removed) of monthly mean sea level and SST show the presence of a multi-year variability of periodicity roughly between 32 and 64 months (Figure 13). The energy of the signal was found to vary over the years. The principal component analysis also showed similar variability, with the first mode of variability explaining nearly $90 \%$ of the variance (Figure 14 ).

a) low passed monthly mean SLA

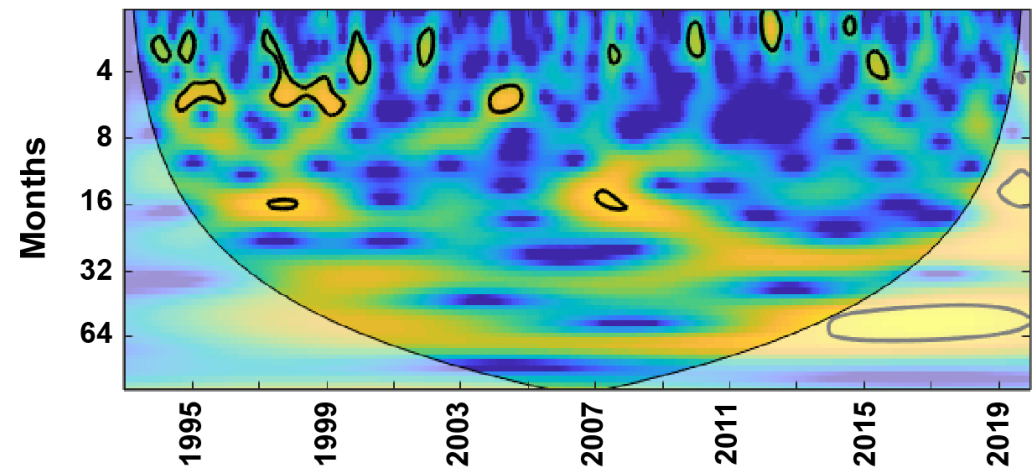

b) low passed monthly mean SST

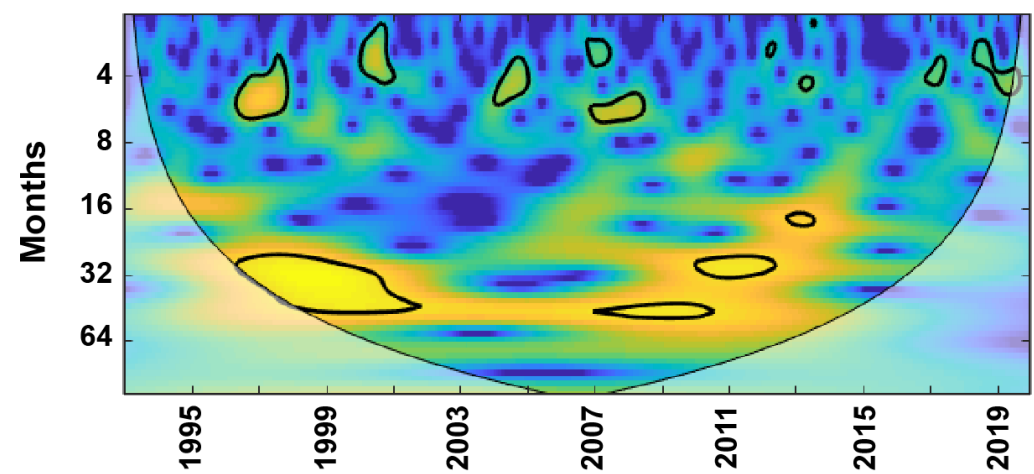

Figure 13. Wavelet analysis for low passed monthly mean sea level.

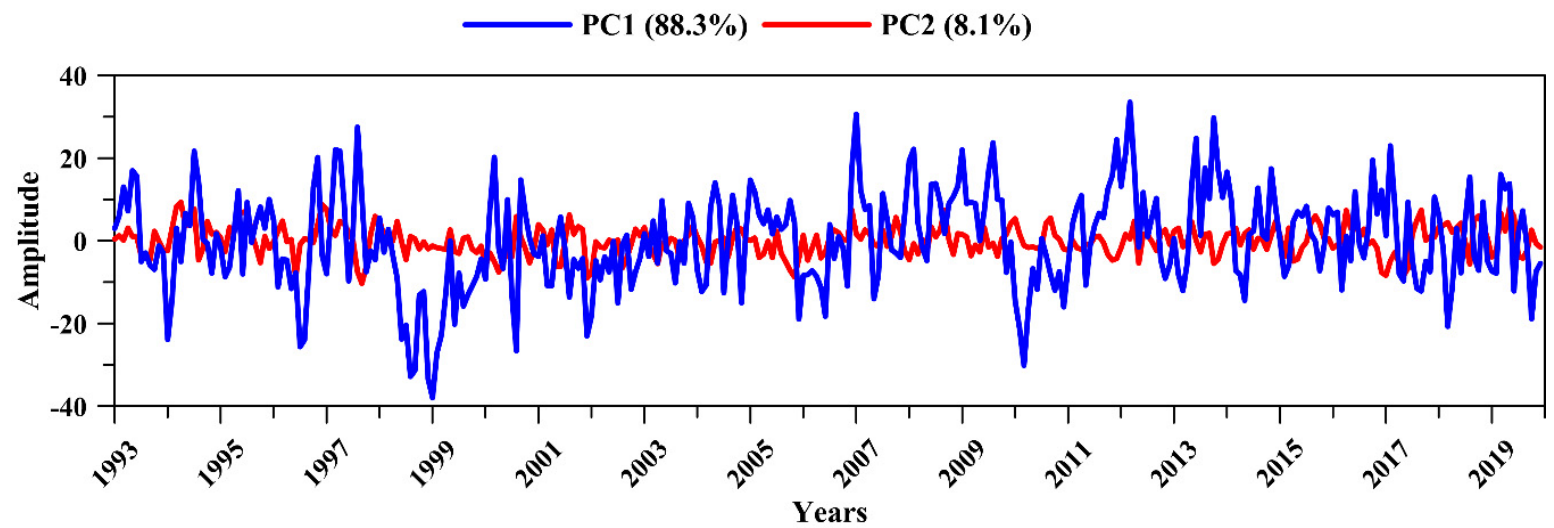

Figure 14. Dominant modes of variability from the principal component analysis for SST.

The long-term variability of SST is shown in Figure 15. The results show that both the northern and southern Gulf have experienced considerable warming over the years of the study period. The rate of increase in SST for the northern Gulf is slightly higher than the southern Gulf, with a linear trend of 0.027 and $0.010{ }^{\circ} \mathrm{C} /$ year, respectively. Considering the post-2000 period alone, the rate of increase in the northern Gulf is slightly higher $\left(0.033{ }^{\circ} \mathrm{C}\right.$ /year), while that of the southern Gulf is slightly lower $\left(0.006{ }^{\circ} \mathrm{C} /\right.$ year $)$. The correlation between sea level and SST in the Northern Arabian Gulf is 0.54, while that of 
the southern side is relatively low (0.28). The average correlation is 0.42 , with a $p$-value of 0.02 .
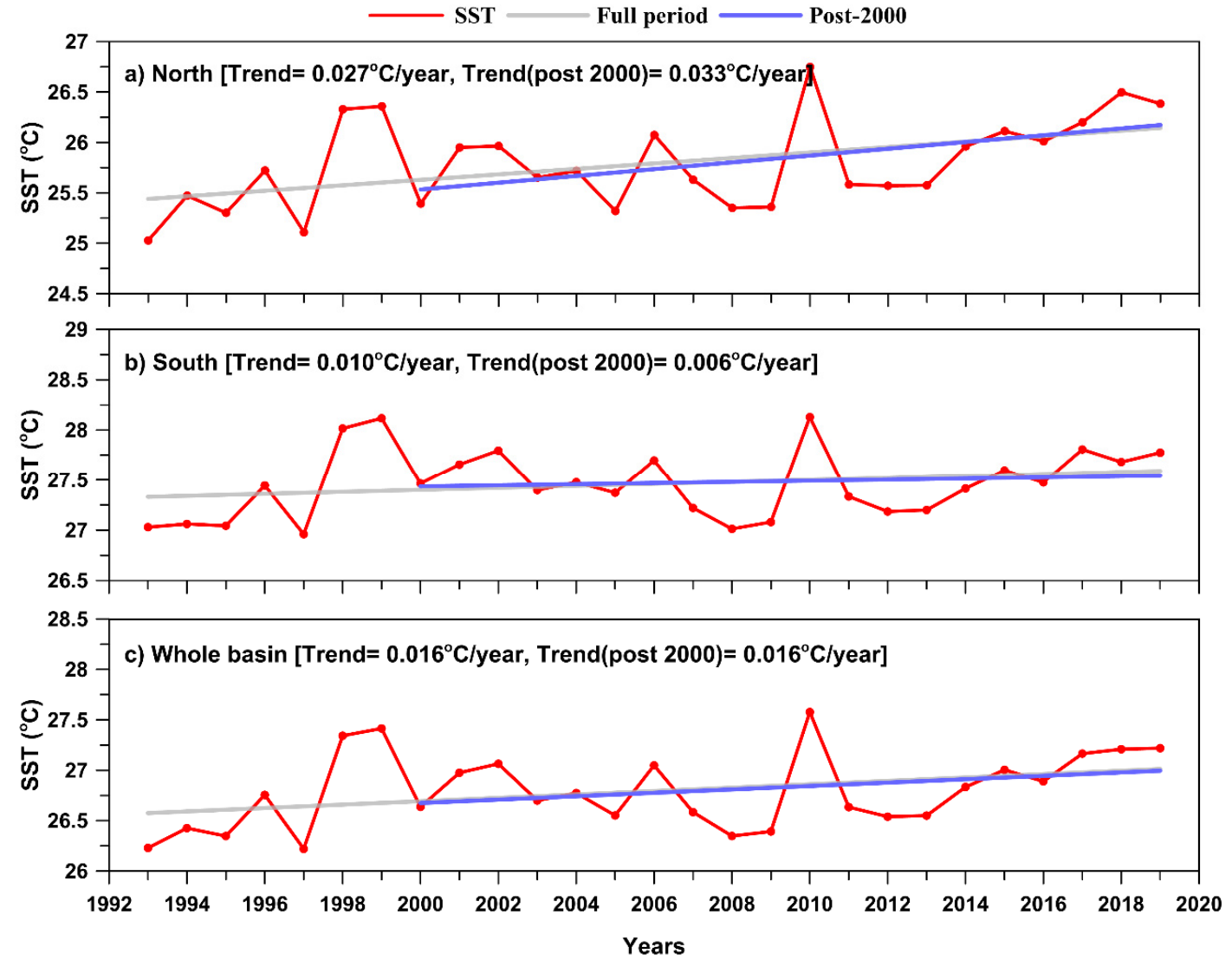

Figure 15. Annual mean SST in the Arabian Gulf for the (a) northern, (b) southern, and (c) whole Arabian Gulf. The linear trends are shown by dashed lines for the full period (green), and the post-2000 period (red).

The expected value of SST from numerical simulations under the RCP2.6, RCP4.5, and RCP8.5 scenarios for the Arabian Gulf is shown in Figure 16. The predicted SST for the Arabian Gulf for the year 2050 is 26.00, 25.94, and 26.80, and for the year 2100 it is 25.34, 26.93, and 28.58, respectively. According to these projections, the SST is expected to rise by $0.55,0.11$, and 2.03 by 2050 for the scenarios RCP2.6, RCP4.5, and RCP8.5, and by -0.11 , 1.11 , and 3.82 , respectively by the end of the 21 st century.

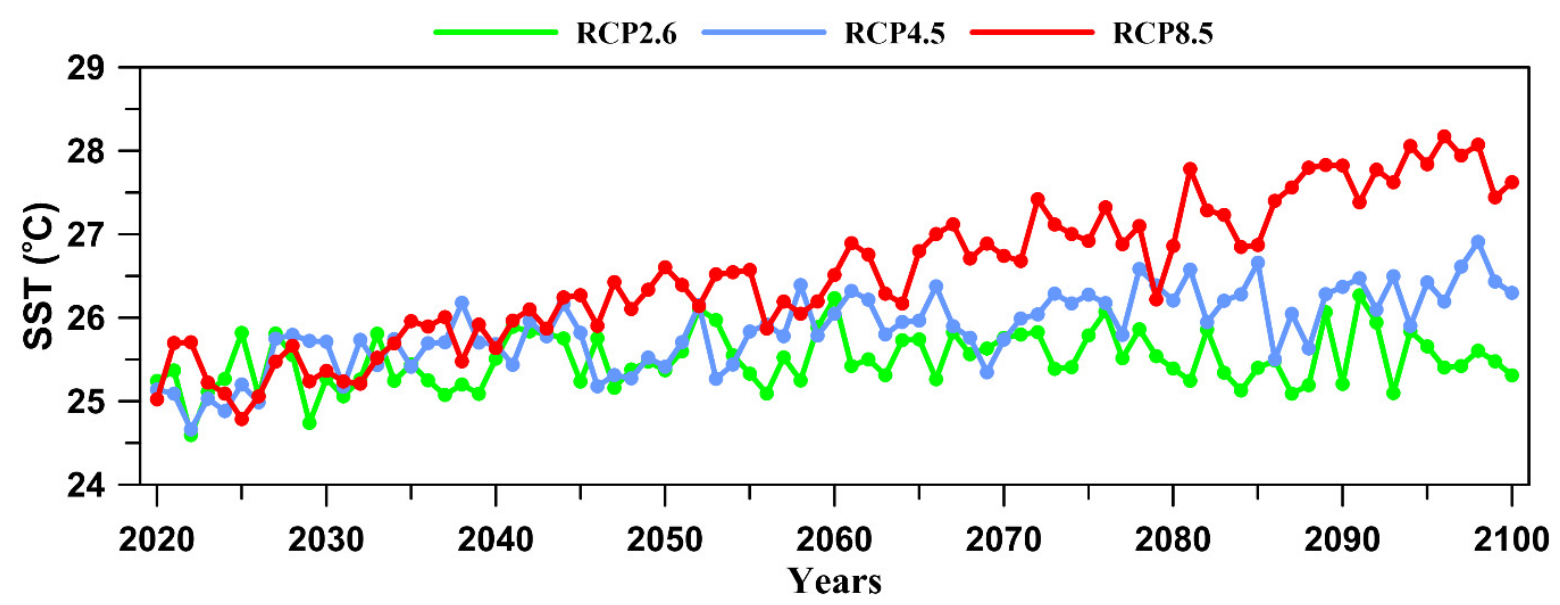

Figure 16. Projected SST for the Arabian Gulf. 


\section{Discussion}

The sea-level variability of the Arabian Gulf is examined with the help of nearly three decades of satellite sea-level observations from 1993 to the present. The monthly, seasonal, and annual climatology of sea level is prepared and the short-term and long-term variabilities are investigated. In agreement with previous estimates $[6,17,23,27,34,35]$, the monthly and seasonal climatology shows that the Arabian Gulf is characterized by a higher sea level during summer and a lower sea level during winter. The annual maximum and minimum sea levels are observed, respectively, during November and April, consistent with past studies $[6,17,27]$. Since the connection of the Arabian Gulf to the world ocean is through the Strait of Hormuz, the lower or higher sea level in the Arabian sea extends to the Arabian Gulf as a tongue-like pattern of lower or higher sea level.

In agreement with the findings of [6], the annual and semi-annual variabilities are dominating in the region. The long-term trend observed in previous studies for the different locations in the Arabian Gulf was $1.7 \mathrm{~mm} /$ year by [24], $2.1 \mathrm{~mm} /$ year by [6], $2.8 \mathrm{~mm} /$ year by [25], and $2.34 \mathrm{~mm} /$ year by [26], based on historical tide gauge datasets. Our results show an average trend of $2.92 \mathrm{~mm} /$ year for the period 1993 to the present. It is to be noted that the sea level increased at a faster rate in recent years, which is one of the reasons for the relatively smaller trend in the earlier studies, where the length of the available data is relatively short and the actual rate of sea level rise was comparatively weaker than in recent years. Moreover, regional differences are visible in the present-day sea-level trend also due to various local and remote factors $[1,4,7,8]$.

The comparison of seasonal cycles in the Arabian Gulf sea level with that of the adjacent basins shows that the pattern of variability in the Arabian Gulf is significantly different from that of the Red Sea (adjacent marginal sea), while the seasonal variability is in agreement with that of the Arabian Sea and the Mediterranean Sea. The possible reason for this is the difference in the impact of wind on the sea level. The dominant pattern of wind in the Arabian Gulf is from the NW direction throughout the year. In the case of the Red Sea, the wind in the Red Sea blows from the NNW during summer, enhancing the outflow of water from the Red Sea and thereby lowering the sea level. During winter, the wind in the southern Red Sea reverses to blow from the SSE, enhancing the inflow of water into the Red Sea and thereby increasing the sea level. The wind in the northern Red Sea during winter is relatively weak. Thus, the difference in the pattern and impact of wind is the major reason for the observed difference in the seasonal cycle between the Arabian Gulf and the Red Sea. The comparison of the spatial differences in the mean seasonal cycle within the basin shows that the Arabian sea has a comparatively higher variability from north to south than that of the Arabian Gulf, Mediterranean Sea, and the Red Sea.

The correlational analysis between sea level and climate indices is relatively low. The correlation values for IOD, ENSO, and NAO events are, respectively, $0.12(p=0.03)$, $-0.01(p=0.86)$, and $-0.16(p=0.01)$. The correlation analysis between sea level and climate indices shows that the direct impact of climate modes (remote forces) is not visible, which indicates that the possible impact on sea level is limited. Future research with the help of sensitivity experiments using numerical models may provide further insight on this.

Previous studies also pointed out that the meteorological conditions are the dominant drivers of sea-level variability over the Arabian Gulf due to the relatively shallow nature of the region, with an average depth of $36 \mathrm{~m}$. The sea-level change is mainly driven by the steric effect and changes in atmospheric pressure [36,37]. The region is characterized by high pressure during winter and low-pressure during summer, leading to lower sea level during winter and higher sea level during summer. The impact of warming and thermal expansion results in the overall increase in annual sea level. The wind pattern in the Arabian Gulf is almost in the same direction throughout the year for most of the region inside the Gulf. However, considerable variation in the wind speed exists. The observed impact of wind on sea level is relatively low in the Arabian Gulf [24,35].

The Arabian Gulf has experienced an increase in the rate of sea-level rise during the post-2000 period. A similar increase is observed in the Arabian Sea also. This can 
be mainly associated with the ongoing global warming, as the steric contribution to sea level is relatively high in both the Arabian Gulf [24,35] and the Arabian Sea [38-40]. The long-term linear trend in SST is positive in the Gulf $\left(0.027^{\circ} \mathrm{C} /\right.$ year in the northern Gulf and $0.010{ }^{\circ} \mathrm{C}$ /year in the southern Gulf), and the future projections of SST show an increase of $2.03{ }^{\circ} \mathrm{C}$ by 2050 and $3.82{ }^{\circ} \mathrm{C}$ by 2100 under the RCP8.5 scenario. Accordingly, the sea level is also expected to rise. The implementation of major movements for minimizing the causes of ongoing warming is required to reduce the rate of sea-level rise to some extent.

It is to be noted that uncertainties are possible in the satellite altimetry data [41]. However, the long-term studies with annual average estimates will considerably minimize such errors from the results. Furthermore, the results from recent studies [27,34,35,42] show that the satellite altimetry estimates are reliable and consistent with the in situ observations in the Arabian Gulf.

\section{Conclusions}

The sea-level climatology and long-term variability in the Arabian Gulf are investigated and compared with the adjacent marginal seas and other world ocean basins. The satellite altimetry data of nearly three decades, from 1993 to the present, are used to carry out these analyses, and the main features of seasonal, interannual, and long-term changes are described. The seasonal variability of sea level in the Arabian Gulf is nearly opposite to that of the adjacent Red Sea basin. Detailed analysis revealed that the observed difference is mainly associated with the difference in wind pattern in the Red Sea and the Arabian Gulf. The mean seasonal cycle showed a significant difference from the directly connected Arabian Sea also, indicating that local forces dominate the seasonal cycle, rather than the exchange between the Arabian Sea and the Arabian Gulf.

The observed trend in the Arabian Gulf's sea level is consistent with global warming and the associated increase in sea level. It is also important to note that the pattern of interannual sea-level variability in the Arabian Gulf is different from the pattern of sea level change in the directly connected Arabian Sea and other selected basins, indicating that local forces are dominant in the interannual variability, rather than remote forces.

The correlation coefficients between the sea level and climate indices are relatively low, indicating that the possible impact on sea level is limited. The sensitivity experiments using numerical simulations may provide further insight on this, which can be executed as a continuation of this work in the future. If contemporary global warming due to different factors including anthropogenic causes with the increase in greenhouse gas concentration continues over the coming years, the projections indicate that sea surface temperature and sea level are expected to increase tremendously, leading to irrevocable harm to human life and socio-economical system. Timely actions to mitigate the concentration of greenhouse gases through sustainable development may help to lessen the impact to some extent.

Author Contributions: Conceptualization, A.M.A.-S., C.P.A.; methodology, C.P.A.; software, C.P.A.; validation, A.M.A.-S.; formal analysis, C.P.A.; investigation, A.M.A.-S., C.P.A.; resources, A.M.A.S.; data curation, C.P.A.; writing—original draft preparation, C.P.A.; writing-review and editing, A.M.A.-S., C.P.A.; visualization, A.M.A.-S., C.P.A.; supervision, A.M.A.-S.; project administration, A.M.A.-S.; funding acquisition, A.M.A.-S. All authors have read and agreed to the published version of the manuscript.

Funding: This research received no external funding.

Institutional Review Board Statement: Not applicable.

Informed Consent Statement: Not applicable.

Data Availability Statement: Publicly available datasets were analyzed in this study. This data can be found here: SLA from http:/ / www.aviso.altimetry.fr/ (accessed on 7 July 2021) and SST from https:/ / podaac.jpl.nasa.gov / dataset/ (accessed on 7 July 2021). 
Acknowledgments: The authors acknowledge the support from AVISO (Archiving, Validation, and Interpretation of Satellite Oceanographic data) by providing satellite maps of sea-level anomaly; PO.DAAC (Physical Oceanography Distribution Active Archive Center) by providing satellite maps of sea surface temperature; the World Climate Research Programme's Working Group by providing future projections of sea-level and sea surface temperature; the NCEP (National Centers for Environmental Prediction) by providing wind data. The authors also acknowledge the Ferret and CDO data analysis tools and thank the team behind them for making the tools freely available for research. The second author acknowledges the support from University Grants Commission, India in the form of the D. S. Kothari postdoctoral fellowship.

Conflicts of Interest: The authors declare no conflict of interest.

\section{References}

1. Church, J.A.; Gregory, J.M. Sea Level Change. Encycl. Ocean Sci. 2001, 2599-2604. [CrossRef]

2. Church, J.A.; White, N.J.; Aarup, T.; Wilson, W.S.; Woodworth, P.L.; Domingues, C.M.; Hunter, J.R.; Lambeck, K. Understanding global sea levels: Past, present and future. Sustain. Sci. 2008, 3, 9-22. [CrossRef]

3. Close, S.; Penduff, T.; Speich, S.; Molines, J.M. A means of estimating the intrinsic and atmospherically-forced contributions to sea surface height variability applied to altimetric observations. Prog. Oceanogr. 2020, 184, 102314. [CrossRef]

4. Cazenave, A.; Hamlington, B.; Horwath, M.; Barletta, V.R.; Benveniste, J.; Chambers, D.; Döll, P.; Hogg, A.E.; Legeais, J.F.; Merrifield, M.; et al. Observational requirements for long-term monitoring of the global mean sea level and its components over the altimetry era. Front. Mar. Sci. 2019, 6, 582. [CrossRef]

5. Piecuch, C.G.; Fukumori, I.; Ponte, R.M. Intraseasonal Sea Level Variability in the Persian Gulf. J. Phys. Oceanogr. 2021, 51, 1687-1704. [CrossRef]

6. Sultan, S.A.R.; Ahmad, F.; Elghribi, N.M.; Al-Subhi, A.M. An analysis of Arabian Gulf monthly mean sea level. Cont. Shelf Res. 1995, 15, 1471-1482. [CrossRef]

7. Nidheesh, A.G.; Lengaigne, M.; Vialard, J.; Unnikrishnan, A.S.; Dayan, H. Decadal and long-term sea level variability in the tropical Indo-Pacific Ocean. Clim. Dyn. 2013, 41, 381-402. [CrossRef]

8. Abdulla, C.P.; Al-Subhi, A.M. Sea level variability in the Red sea: A persistent east-west pattern. Remote Sens. 2020, 12, 2090. [CrossRef]

9. De Verdière, A.C.; Huck, T. Baroclinic instability: An oceanic wavemaker for interdecadal variability. J. Phys. Oceanogr. 1999, 29, 893-910. [CrossRef]

10. Pierini, S. A Kuroshio Extension system model study: Decadal chaotic self-Sustained oscillations. J. Phys. Oceanogr. 2006, 36, 1605-1625. [CrossRef]

11. Huck, T.; Arzel, O.; Sévellec, F. Multidecadal variability of the overturning circulation in presence of eddy turbulence. J. Phys. Oceanogr. 2015, 45, 157-173. [CrossRef]

12. Kanzow, T.; Johnson, H.L.; Marshall, D.P.; Cunningham, S.A.; Hirschi, J.J.; Mujahid, A.; Bryden, H.L.; Johns, W.E. Basinwide integrated volume transports in an eddy-filled ocean. J. Phys. Oceanogr. 2009, 39, 3091-3110. [CrossRef]

13. Hirschi, J.J.M.; Killworth, P.D.; Blundell, J.R.; Cromwell, D. Sea surface height signals as indicators for oceanic meridional mass transports. J. Phys. Oceanogr. 2009, 39, 581-601. [CrossRef]

14. Clément, L.; Frajka-Williams, E.; Szuts, Z.B.; Cunningham, S.A. Vertical structure of eddies and Rossby waves, and their effect on the Atlantic meridional overturning circulation at $26.5^{\circ}$ N. J. Geophys. Res. Ocean. 2014, 119, 6479-6498. [CrossRef]

15. Deepa, J.S.; Gnanaseelan, C.; Mohapatra, S.; Chowdary, J.S.; Karmakar, A.; Kakatkar, R.; Parekh, A. The tropical Indian Ocean decadal sea level response to the Pacific decadal oscillation forcing. Clim. Dyn. 2019, 52, 5045-5058. [CrossRef]

16. Alawad, K.A.; Al-Subhi, A.M.; Alsaafani, M.A.; Alraddadi, T.M.; Ionita, M.; Lohmann, G. Large-Scale Mode Impacts on the Sea Level over the Red Sea and Gulf of Aden. Remote Sens. 2019, 11, 2224. [CrossRef]

17. Reynolds, R.M. Physical Oceanography of the Persian Gulf, Strait of Hormuz, and the Gulf of Oman-Results from the Mt. Mitchell Expedition. Mar. Pollut. Bulletin. 1993, 27, 35-59. [CrossRef]

18. Privett, D.W. Monthly charts of evaporation from the N. Indian Ocean (including the Red Sea and the Persian Gulf). Q. J. R. Meteorol. Soc. 1959, 85, 424-428. [CrossRef]

19. Ahmad, F.; Sultan, S.A.R. Annual mean surface heat fluxes in the Arabian Gulf and the net heat transport through the Strait of Hormuz. Atmos.-Ocean 2010, 29, 54-61. [CrossRef]

20. Xue, P.; Eltahir, E.A.B. Estimation of the heat and water budgets of the Persian (Arabian) gulf using a regional climate model. J. Clim. 2015, 28, 5041-5062. [CrossRef]

21. Hunter, J.R. Aspects of the Dynamics of the Residual Circulation of the Arabian Gulf; Springer: Boston, MA, USA, 1983. [CrossRef]

22. El-Gindy, A.A.H. Sea Level Variations and their Relations to the Meteorological Factors in the Arab Gulf Area with Stress on Monthly Means. Int. Hydrogr. Rev. 1991, 1, 68.

23. Al-Subhi, A.M. Tide and sea level characteristics at Juaymah, west coast of the Arabian Gulf. J. King Abdulaziz Univ. Mar. Sci. 2010, 21, 133-149. [CrossRef] 
24. Sultan, S.; Moamar, M.; El-Ghribi, N.; Williams, R. Sea level changes along the Saudi coast of the Arabian Gulf. Indian J. Mar. Sci. 2000, 29, 191-200.

25. Hassanzadeh, S.; Kiasatpour, A.; Hosseinibalam, F. Sea-level response to atmospheric forcing along the north coast of Persian Gulf. Meteorol. Atmos. Phys. 2007, 95, 223-237. [CrossRef]

26. Hosseinibalam, F.; Hassanzadeh, S.; Kiasatpour, A. Interannual variability and seasonal contribution of thermal expansion to sea level in the Persian Gulf. Deep. Res. Part I Oceanogr. Res. Pap. 2007, 54, 1474-1485. [CrossRef]

27. Alothman, A.O.; Bos, M.S.; Fernandes, R.M.S.; Ayhan, M.E. Sea level rise in the north-western part of the Arabian Gulf. J. Geodyn. 2014, 81, 105-110. [CrossRef]

28. Antonov, J.I.; Levitus, S.; Boyer, T.P. Thermosteric sea level rise, 1955-2003. Geophys. Res. Lett. 2005, 32, 1-4. [CrossRef]

29. Legeais, J.F.; Ablain, M.; Zawadzki, L.; Zuo, H.; Johannessen, J.A.; Scharffenberg, M.G.; Fenoglio-Marc, L.; Joana Fernandes, M.; Baltazar Andersen, O.; Rudenko, S.; et al. An improved and homogeneous altimeter sea level record from the ESA Climate Change Initiative. Earth Syst. Sci. Data 2018, 10, 281-301. [CrossRef]

30. Nerem, R.S.; Beckley, B.D.; Fasullo, J.T.; Hamlington, B.D.; Masters, D.; Mitchum, G.T. Climate-change-driven accelerated sea-level rise detected in the altimeter era. Proc. Natl. Acad. Sci. USA 2018, 115, 2022-2025. [CrossRef] [PubMed]

31. Saha, K.; Dash, P.; Zhao, X.; Zhang, H. Error Estimation of Pathfinder Version 5.3 Level-3C SST Using Extended Triple Collocation Analysis. Remote Sens. 2020, 12, 590. [CrossRef]

32. Saha, S.; Moorthi, S.; Wu, X.; Wang, J.; Nadiga, S.; Tripp, P.; Behringer, D.; Hou, Y.-T.; Chuang, H.; Iredell, M.; et al. The NCEP Climate Forecast System Version 2. J. Clim. 2014, 27, 2185-2208. [CrossRef]

33. Stammer, D.; Cazenave, A.; Ponte, R.M.; Tamisiea, M.E. Causes for contemporary regional sea level changes. Ann. Rev. Mar. Sci. 2013, 5, 21-46. [CrossRef]

34. Siddig, N.A.; Al-Subhi, A.M.; Alsaafani, M.A.; Alraddadi, T.M. Applying Empirical Orthogonal Function and Determination Coefficient Methods for Determining Major Contributing Factors of Satellite Sea Level Anomalies Variability in the Arabian Gulf. Arab. J. Sci. Eng. 2021, 1, 1-10. [CrossRef]

35. Siddig, N.A.; Al-Subhi, A.M.; Alsaafani, M.A. Tide and mean sea level trend in the west coast of the Arabian Gulf from tide gauges and multi-missions satellite altimeter. Oceanologia 2019, 61, 401-411. [CrossRef]

36. Emery, K.O. Sediments and Water of Persian Gulf. Am. Assoc. Pet. Geol. Bull. 1956, 40, 2354-2383. [CrossRef]

37. Lisitzin, E.; Pattullo, J.G. The principal factors influencing the seasonal oscillation of sea level. J. Geophys. Res. 1961, 66, 845-852. [CrossRef]

38. Swapna, P.; Jyoti, J.; Krishnan, R.; Sandeep, N.; Griffies, S.M. Multidecadal Weakening of Indian Summer Monsoon Circulation Induces an Increasing Northern Indian Ocean Sea Level. Res. Lett. 2017, 44, 10560-10572. [CrossRef]

39. Parekh, A.; Gnanaseelan, C.; Deepa, J.S.; Karmakar, A.; Chowdary, J.S. Sea Level Variability and Trends in the North Indian Ocean. In Springer Geology; Springer: Singapore, 2017; pp. 181-192.

40. Salim, M.; Nayak, R.K.; Swain, D.; Dadhwal, V.K. Sea Surface Height Variability in the Tropical Indian Ocean: Steric Contribution. J. Indian Soc. Remote Sens. 2012, 40,679-688. [CrossRef]

41. Prandi, P.; Meyssignac, B.; Ablain, M.; Spada, G.; Ribes, A.; Benveniste, J. Local sea level trends, accelerations and uncertainties over 1993-2019. Sci. Data 2021, 8, 1. [CrossRef]

42. Abdulla, C.P.; Al-Subhi, A.M. Is the Red Sea Sea-Level Rising at a Faster Rate than the Global Average? An Analysis Based on Satellite Altimetry Data. Remote Sens. 2021, 13, 3489. [CrossRef] 